\title{
BARRACAS ON THE MEDITERRANEAN COAST
}

\author{
Juan A. García-Esparza \\ Department of Mechanical Engineering and Construction \\ Campus del Riu Sec, E.S.T.C.E., Universitat Jaume I de Castelló, España \\ Tlf: +34 651130 773; Tlf: +34 964729162 email: juan.garcia@emc.uji.es \\ Short title: Barracas, a vernacular dwelling.
}

\section{ABSTRACT}

The article takes a cultural heritage approach to present a scientifically rigorous historical analysis of a traditional building method. A series of detailed monographs are referred to. The paper discusses the Central European conservation theories of 'Heimatschutz' at the beginning of the $20^{\text {th }}$ century and the ideals of Krausism to determine a direct relationship between narrative art and photography as a threshold to the heritage analyzed.

The study begins with a metric analysis of the barraca, a typical one-story thatched farmhouse in the Valencia area, and examines its construction and pathology; it presents a breakdown of the construction's constituent parts through diagrams to offer a greater understanding of its creation and subsequent processes of transformation.

The study departs from the strict reinterpretation of traditional building techniques to adopt an approach that examines the use of its component materials, thus providing an understanding of interventions that are compatible with conservation.

Keywords: farmhouse, traditional techniques, vernacular dwelling, heritage, Heimat. 


\section{INTRODUCTION}

Architectural descriptions or classifications can take different forms: vernacular, related to a place, territory or country; native, related to the land or territory; typical, offering a quaint, delightful image; traditional, set in the transmission of customs and manners; self-constructed, built by the owner; without architects, not designed by experts or builders, etc. However, Spanish history has adopted the term 'popular', as was widely used in the 20s and 30s of the last century (Torres Balbás, 1933).

The paper I present is a personal one, involving some four years' research to classify the last centenarian barracas ${ }^{1}$ that still remain in Valencia and the surrounding areas. I establish analogies with other areas at a national and international level and explain the intricacy of its maintenance and conservation in detail by describing the building process and the traditional techniques, since the study of popular housing cannot be separated from the characteristics of its habitat, that is, its physical environment.

Of the different positions from which popular housing can be studied, I essentially take an architectural and ethnographic position for both professional and personal interests, with the aim of shedding new light on the development of the barraca, thus allowing us to examine and correctly classify the extremely poor legacy that is left today, and avoid ambiguity or misinterpretations. These vernacular constructions, located on the Mediterranean coast, were used as dwellings over many generations and the samples analyzed show how various construction phases have satisfied the needs of their inhabitants and have always been highly valued by them.

The aim of this paper is to offer a useful insight into a vernacular shelter that provides not only a documentary record, but a guide for further research on old popular housing types that are now gradually disappearing; it should be remembered that although many settlements are

\footnotetext{
${ }^{1}$ Typical one-story thatched farmhouse in the area of Valencia
} 
considered to be insignificant, ordinary and humble, the true spirit of their societies lies within them.

\section{METHODS}

Producing an extensive catalogue on building methods requires prior awareness of the extent of the task to be undertaken, involving intense research into the history of the subject, preliminary studies and the complex process of morphological changes in building due to changes in the environment in recent decades. As a prior step to field work, I attempted to find similar studies that might help to geographically locate the buildings, but my search for relevant information proved fruitless. The fieldwork followed an examination of planimetric and general maps, and other graphic material from the municipalities in the area. With the help of the Geographical Information System (GIS) and Global Positioning System (GPS), but basically with a good deal of patience and willingness to comb the area inch by inch only using a motorbike adapted to the terrain, data gathering began at the beginning of 2004, and continues to date. An initial file card was created and modified as the study progressed and the data obtained. Manual and electronic methods were used to measure the barracas. A digital camera was always used, either compact or reflex depending on the circumstances; the last photographs were taken with a Canon EOS 400 D.

Many have been the roads covered, many itineraries have been repeated, empty houses, missed calls, happy and sad situations, chats, dead silence, refreshing drinks, night falling... A series of situations that have enriched an experience that has been both gratifying and fascinating. The final and perhaps most demanding phase of the research was to transfer the information from the file cards to digital format. Transcription of all the information, storing the photographs, compiling and ordering the maps to create a single document was undertaken with computer programs such as Microsoft Word, Publisher and PowerPoint, Adobe Photoshop 7.0, Adobe Acrobat 7.0 and Autocad 2005 on an HP Pavillion ZV 5000 PC, 
to obtain the global view presented in this paper and in the catalogue of accompanying files.

(Fig.1) 


\section{LINE OF ARGUMENT AND DISCOVERIES}

\section{DISCOVERY OF THE BARRACA IN THE CULTURAL PROCESS}

\subsection{PRELIMINARY STUDY}

At the end of the $19^{\text {th }}$ century, Spain was a refuge for the 'natural' artistic perception of a country whose art continued to be the highest and most genuine expression of its culture, not yet corrupted by the haste of the industrial revolution. Cultural pessimism and essential thinking created a common denominator, from which the vernacular reference became one of the specific recurrent subjects in architecture at the beginning of the twentieth century. The nostalgic defense of local values emerged from the sense of establishing roots in the fatherland, the Heimat, the traditionalist movement created between Spain and Germany in the first four decades of the $20^{\text {th }}$ century (Medina, 2002).

Cultural traditions of the Spanish Regeneration, such as Krausism, were rooted in German Idealism and Romanticism. These romantic movements were related to and sprang from the picturesque spirit and the anti-urban criticism that spawned the idyllic Rousseauvian views characteristic of the second half of the $18^{\text {th }}$ century, particularly in connection with the Age of Enlightenment. Hence, the rural country dwelling would become the architectural prototype of the period and European books and treatises of contemporary architecture on this subject were filled with designs of villas, and even farmhouses, as the first examples of popular architecture (García-Esparza, 2004-2007).

Education based on Krausist philosophy brought the student directly into contact with nature and with any subject under study; experimental classes and field trips therefore played an important role. This movement gave rise to the Free Institution of Education whose influence was lasting and fertile in artistic and intellectual circles between 1876 and 1936 when scholars of art who came from Central Europe (Pérez, 1985) and other local authors began extensive surveys of the Spanish territory. Many of them came to the Mediterranean coast and in their 
endeavors to study the landscape, habits and customs of the rural population, discovered the building studied in this paper, the barraca, which they mentioned, described or illustrated.

The first summary of popular Spanish architecture is found in the work of the architect, historian, restorer and professor of the History of Architecture at the School of Architecture, Madrid, Vicente Lampérez y Romea (1861-1923) who devoted a significant chapter to rural architecture (Lampérez, 1922).

With regard to the ideals of Heimatschutz, the work of architect, critic and ethnographer, Alfredo Baeschlin (1883-1964), founder of the Swiss Association of Homeland Protection, is particularly noteworthy. He traveled to Barcelona around 1918 before visiting the Basque Country and finally settling in Valencia in 1930 until his deportation in 1942. From the conservative traditionalism of the beginning of the century, through the 'arcadia of noucentisme ${ }^{2}$, we arrive at national treatise writers who, to a greater or lesser extent, studied the notion of what we regard as popular. One of these writers was Leopoldo Torres Balbás (1888-1960), who after organizing the Charro-Hidalgo Contest in the Madrid Ateneo in 1923 under the title 'Popular Architecture of the Spanish regions' went on to publish a considerably extended version of his detailed study of the Spanish house (Nieto, 1968), in which he describes the material nature of the barracas from three similar geographical areas on the Mediterranean coast (Torres Balbás, 1933).

Also of note is the work of Victor Gosálvez (1888-1965) who, together with his father, master builder Juan Bautista Gosálvez, and the architect Angel Romaní, was responsible for most of the new constructions and rebuilding work in El Cabañal-Cañamelar between 1900-1936, when barracas were replaced by houses. His manuscript included drawings and photographs to illustrate his observations on the materials, systems and building processes of the Valencian barraca and the economic and social reasons for its disappearance (Gosávez, 1998). Fritz

\footnotetext{
${ }^{2}$ Early $20^{\text {th }}$ cultural movement in Catalonia.
} 
Krüger (1889-1974), an outstanding German professor of Romance languages, settled in Spain at the beginning of the $20^{\text {th }}$ century to study the languages of the north of the peninsula; he also sent students from Hamburg University, such as Max Thede, to complete a thorough study of the Albufera of Valencia (Thede, 1932). The report appeared in several articles published in a Hamburg journal by Fritz Krüger 'Volkstum und kultur der Romanen'.

Fernando García Mercadal (1896-1985), together with the architects Aizpurua, Sert and Torres Clavé founded GATEPAC (Grupo de Artistas y Técnicos Españoles para la Arquitectura Contemporánea). As part of this group, García Mercadal linked Spanish architecture with that of the rest of Europe (Tarragó, 1980), emphasizing the social function of architecture and urban development. The group's interest not only lay in the architectural vanguard but also in regional architecture, based on the use of resources taken from local architecture that would be taken up in subsequent reports (García Mercadal, 1980).

\subsection{LITERATURE, THE THRESHOLD TO OUR CULTURAL HERITAGE}

Not only written documentation, archeological objects and monuments can testify to our history and traditions. Literature and oral accounts are also a powerful means of rediscovering the collective imagination. Articles on customs documented the barraca typologies, trades and popular customs that were inclined to disappear with the advance of bourgeois society.

The literary works of Vicente Blasco Ibañez marked the end of Spanish realism, a movement on which he had a major impact. His series of local Valencian novels, the first of which, ' $\mathrm{La}$ Barraca', is considered to be his best, most poetic, thorough and imaginative work, shows us how many people who, incapable of recognizing the value of the traditional lifestyle are not slow to condemn it. His work outlines for the first time the social concerns of the agricultural workers who are tied to their dwellings (Cardwell, R. 1994:53).

Genres tended to merge in the narrative prose of this period, with the essay becoming predominant. At times the novel was speculative and structured in thoughtful descriptions; in 
other examples it gave a typical detailed description closer to poetry, but always in line with the new literary style that was spreading through Valencian society, which served to promote tourism and give the typical barraca the appreciation it deserved. 


\section{THE PAPER'S CONTRIBUTION TO THE UPKEEP AND IMPROVEMENT OF}

\section{CULTURAL HERITAGE}

\section{THE BARRACA: A VERNACULAR BUILDING}

\subsection{ANALYSIS OF THE ENVIRONMENT}

Geographically, the barraca is located on a narrow coastal strip between the Ebro Delta and the fields of Orihuela. Examples of the construction continue to exist in this area.

The most important variations are found on the coast and reflect the varied lifestyles of its occupants: the old seasonal shacks of the fishermen from Puig and Puzol; the more permanent dwelling places of the fishermen from Saler; the lake dwellings designed to provide storage for fishing tackle in the Albufera and the secluded barracas in El Palmar, used by fishermen who also cultivated rice (Ciscar, 1974).

\section{GENESIS, DEVELOPING MILESTONES}

The more primitive and basic the shelters, the more they depend on the environment. Hence, this type of humble architecture has been called natural, and the importance of the geographical description of the environment surrounding these vernacular buildings is justified. An analysis and comparison with other regions indicates that they are essentially determined and differentiated by a series of factors: the relief of the land in which they are located; the climate; the vegetation and fauna; and the social aspects of the community; in other words, the physical and human environment that make up the complex modern concept of the natural region.

Three main areas survive as a reminder of past ways of life in which the farmer lived in a barraca, a basic cottage characteristic of regions with a mild climate, where people spend most of the time outdoors, and in which the intensive cultivation of a small piece of land is highly productive and demands full-time dedication. These areas are: the Turia Delta, 
covering the fields and the Valencian Albufera; the Segura Delta, which includes the fields of Orihuela and Murcia; and the Ebro Delta (Torres Balbás, 1933).

The documents published in Aureum Opus -the legal entity of the City and Kingdom of Valencia- state: 'King Jaime permitted the construction of houses instead of barracas and other existing dwellings belonging to fishermen and seamen, which gave rise to the settlement of Villanova maris Valencie' (Mateu, 1955). (Fig.2)

Whether due to these changes on the coast, or to the spread of intensive cultivation in the fields, when expansion began significant changes were observed in the characteristics of the buildings, which progressed from the simple hut, defined as a building made of light materials, to houses constructed with solid building materials.

The type of rooms therefore varied according to the length of time spent indoors. Dwellings built to provide shelter for seasonal jobs did not need to be permanent constructions; however, where activity was more intense, farmers were required to spend practically all their time on their lands. Consequently, the constructions in the Valencian field are more complex or developed than their equivalents in the Ebro and Segura areas.

\subsection{BUILDING ANALYSIS}

The barraca that has survived to the present day is a consequence of continuous developments in construction.

Bearing in mind the complexity of development and the simplicity of the techniques used, the study considers each part of the house in turn in order to better understand its creation and subsequent transformation processes.

These changes parallel the evolution of building in popular architecture that shifted from improving on traditional techniques, to make way for a hybrid vernacular-industrial architecture that is eminently popular, renewed, modified and altered by owners with $20^{\text {th }}$ century materials. 


\subsubsection{ORIGINS OF THE BUILDING METHODS}

\section{THE GROUND FLOOR}

In his paper on Architecture and Archeology, Maldonado established the relationship between the internal organization of the dwelling and its shape (Maldonado, 1997:34). He associated a circular shape with nomadic and semi-nomadic societies, while square and rectangular constructions were identified with sedentary societies. Indeed, circular structures seem to have given way to rectangular ones for at least two reasons: the possibility of introducing rectangular structures when the family grew in size, and the increase in production favored by demographic growth, population concentration and social organization. (Fig.3)

This theory is endorsed by F. Oelman who considers the barraca of El Palmar to represent a transition from the round hut with a conical roof to the quadrangular hut with an apex roof. Wilhelm Giese goes further in supporting Oelman's theory by adding that the round shape of the floor is a continuation of the primitive form seen in circular huts (Giese, 1951).

\subsubsection{DEVELOPMENT OF TRADITIONAL TECHNIQUES}

\section{THE STRUCTURE}

Evolution in the construction of the barraca is related to the advantageous use made of wood in the skeleton roof. Rough tree branches gave the roof a more solid structure. A two-sided sloping roof was used. The structure evolved from one in which the hard, sun-dried branches were firmly anchored in the ground, to one with a pseudo roof structure, which starting at ground level, consisted of two main truss posts bearing a longitudinal beam on which the roof rafters were supported.

To mitigate the pressure to which the structure is subject because of its size, the slope of the roof and consequently its exposure to side winds, wooden crossbeams are nailed from one side to another at a height that does not hinder the performance of household chores inside the 
barraca.

The east-west orientation of the barraca is designed to take advantage of the sea breeze. To avoid structural strains deriving from the frontal exposure of the gable ends to these winds, vientos were put in place: small wooden pieces of wood that brace the rafters longitudinally. These diagonal braces form the vientos that cover the whole gable.

According to Max Thede, and with further references by Sanchis Guarner, the structure consisted of a series of rafters anchored to cadorsa and carena (large and small sized beams) respectively and jointed by means of a tie beam strategically located at an appropriate height to allow a person to move around in this single room. This tie beam worked in compression, by horizontally transferring the strain originating on one side of the roof to the other side. (Fig.4)

\section{ADOBE WALLS}

Initially, the walls were constructed with a framework of interwoven vegetation on which layers of clay were successively added, both internally and externally, until a certain thickness was obtained. In a rural area with intense construction, timber to support the structure was likely to be in short supply. Building methods were therefore simplified and the supporting walls were then built with clay bricks. Initially, these adobe bricks were laid before they were completely dry, until the technique was eventually perfected; they were coated on both sides with a layer of clay a few centimeters thick. Use of adobe bricks increased the thickness of the walls, and hence a greater thermal inertia and improved structural stability, especially at the base (Houben, 1994).

The resistance of adobe, made of a mixture of clay and straw, is undoubtedly lower than that of baked brick and varies between 5 and $20 \mathrm{~kg} / \mathrm{cm}^{2}$ depending on whether it is semi-humid or completely dry (AA.VV.1986). The straw counteracts the internal strains that appear during the drying process and provides greater consistency to the dry adobe to counteract mechanical 
strains.

Common reed, phragmites communis, obtained from river banks, was probably cut in the same way it had been for centuries: during the waning moon in winter when the sap lies dormant at the roots. The tradition of cutting wooden material at the right time to avoid premature decay is mentioned by Vitruvius, who attributes the origin of this custom to primitive architecture.

Some of the demolished or abandoned barracas analyzed during the research revealed the correct assembly of the adobe by interlacing cane only in the four corners where the walls meet. This reinforcement prevented pathologies caused by differential settlements, and arrested the effect of bulges, retraction and thermal protraction.

The Babylonian culture may be regarded as the forerunner of this technique of in-filling between the walls (Montero, 2005). These bundles of reeds, evenly distributed in strata at different heights of the building, helped to distribute the strain and tightened the structure in independent layers.

To avoid pathologies due to the inclemency of the weather, the barraca was whitewashed inside and outside every year, coinciding with local festivities. (Fig.5)

\section{FRAMEWORK OF NATURAL MATERIALS}

The use of clay with a timber framework is considered to be a craft, since it is a technique based on natural materials used individually or combined with others.

The framework is a structure built with wooden pieces, sometimes machined, of considerable dimensions used for bracing frames that form the wall; these frames are complemented with a thinner substance, usually made of reeds, joined together by organic fibers or nails. In order for the wall to be functional, the gaps must be filled with clay, particularly argillaceous clay or a mixture of clay and other materials.

At the same time, the evolution of the interweaving of natural materials for roofs, gables and 
the interior walls led to the technique of using reeds known as 'master reeds'. This technique is applied to the roof, attic and gables, which were later coated on only the most exposed side, while the intrados showed the structure as it was, uncoated.

The coating and whitewashing mortar applied to the layers of reeds were the same as those for the adobe walls. The exterior walls of the cottages of the Ebro and Segura were erected using this technique while those of the Turia were replaced by strong adobe walls, only using the former for the interior. (Fig.6 $a, b$ )

\section{THE ROOF}

The roofs have been constructed with great skill and mastery for centuries using the master reed technique. The steep slope (between 45 and 120\%) achieves a balance between resistance to the wind and the need to drain the water as quickly as possible to prevent decay of the thatching material (Nourissier, 2002).

The herbaceous material (reed, Phragmites communis; sedge, Cladium mariscus; marram grass, Ammophila arenaria; bulrush or common cattail, Typha latifolia) was woven upwards onto the reed from the eave towards the ridge, forming a thick cover made of flat bundles 10$25 \mathrm{~cm}$ wide and 40-80 $\mathrm{cm}$ long. This material was always used for the thatch as it was particularly resistant to decay and is typical of lake areas (Ruíz, 1999).

The ridge was finished off with a clay and lime mortar to hide all the bundles of thatch that met in the upper vertex of the roof, thus preventing roof leaks. (Fig.7)

\subsubsection{BARRACA DIMENSIONS}

One of the characteristics of the reform introduced by King Jaime I was the mechanism applied to control measurements by means of very thorough regulation. This reform established the official post of Mustacaf of the City of Valencia towards the end of the $14^{\text {th }}$ century, charged with overseeing weights and measures in the city.

The basic units of reference were the foot and yard, although the cubit and the span were also 
used. In Valencia the yard was subdivided into four spans as well as three feet; the span into four quarters or twelve inches (Corachan, 1735). The use of the span that predominated in Valencia led to the division of the yard into four spans (García, 1988). All the barracas studied correspond to dimensions that followed a system prior to the current metric system.

The size of the dwelling was calculated according to these premises, and depended on the needs of each family. No strict limits were set to the total final dimensions.

The dimensions in evidence today have been modified to a greater or lesser extent by changes made to the roof or the addition of new coatings to the original wall. (Fig.8)*

*Sketch from file cards

\section{POLITICAL CONSEQUENCES AND RESTORATION}

Popular art dies as a result of stagnation due to loss of interest and degradation resulting from repetitiveness, but above all, because of the global process of uniformity, haste and progress. The traditional lifestyle is undergoing transformation or is disappearing all together (Torres Balbás, 1933).

Traditional building materials (clay, wood, reed, etc.) have been replaced by industrial materials (concrete, bricks, fiber cement, aluminium, etc.) across the whole Mediterranean area.

The uniformity of materials is heightened by the commonality of the errors and banality in their use. The main problem derives from the galloping colonization of traditional building methods by new industrialized materials.

Maintenance of existent barracas by traditional and/or compatible techniques is disappearing. Existing methods should be maintained as far as possible without overburdening owners who take it upon themselves to restore their properties. While traditional techniques may be left to one side, restoration would be acceptable so long as the original materials are used. Restoration of the Valencian barraca, constructed as described above, requires great care and 
is consequently a delicate task if changes that adversely affect the present dwelling are to be avoided.

\section{RECOVERY OF BUILDING TECHNIQUES}

\subsection{ADOBE}

Technique: This consists of making bricks from a mix of clay and sandy earth, and organic fibrous material, using simple wooden molds into which the mortar is pressed manually. This technique has different local names, but all bricks are made in practically the same way. The bricks require 2-3 weeks to dry in the sun; they are not fired in a kiln (De Hoz, 2003:57).

Restoration: Any work on adobe walls may be irregular, depending on the state of the walls. Three levels of damage are considered:

Superficial erosion: Superficial loss of adobe due to the detachment of the coating and overexposure to the inclemency and erosion of the weather. Walls can be repaired by thickening the external layer using the same conglomerate as the final coating shown in the first sketch.

Loss of a section: Loss of up to one third of the thickness in any area. Taking into consideration the difficulty of restoring such a large volume, a similar mixture to the original mortar used to make adobe bricks can be applied, with the addition of lime to improve its adherence. Adhesive materials between the traditional wall and the restored section are essential.

Missing wall: Significant loss of the wall in which a section has disappeared completely, and many pieces are missing. In this case, new adobe bricks should be made to match existing sections to avoid bulges, following the techniques described in old documents, and with a similar composition to that of the existing wall so that the original and the rebuilt sections are statically compatible.

\subsection{VERTICAL FRAMEWORK}


Technique: The framework structure is made of large organic pieces used to brace the frames that make up the walls. These frames are usually complemented by reeds, joined together by organic fiber or nails. Any gaps in the internal dividing walls should be filled with earth, particularly argillaceous clay or a combination of clay and other materials applied to both sides of the wall (Bordou-Arzoumanian, 1986). (Fig.9)

Restoration: Repair of these walls will depend on their condition:

Loss of strength: If the wall is considerably out of shape, it must be corrected by an auxiliary structure that will help it recover its original state. Installing wooden props from the floor and anchored to the ceiling can help strengthen it.

Missing wall: The percentage of missing wall should be estimated and actions then taken accordingly. Because of the simplicity of this technique, several solutions can be adopted. Whether only the missing section is repaired or the entire wall rebuilt will depend on each individual case, although the old clay coating will necessarily have to be removed and subsequently restored.

\subsection{THATCHING}

Technique: The organic material was woven onto the reeds, working in an upward direction from the eave to the ridge in flat bundles $10-25 \mathrm{~cm}$ wide and 40-80 cm long, making up a dense coat on the roof. Plant materials with high resistance to decay were always used. They provided good insulation when a covering of at least one third of the volume of the thatch was applied.

The disadvantages of thatching materials are fire and the weakness of the fastenings that join the gavillas, or bundles, to the structural frame. The ridge was finished off with a clay and lime mortar.

Restoration: This technique does not allow for partial repair. In fact, the thatching material was always renewed cyclically. Very few surviving barracas still have this organic roofing 
material today. In view of this loss, every effort should be made to conserve a building technique that is complex, endemic and in danger of dying out. To this end, the accumulated knowledge of the farmers from the south of the area and the Albufera must be retrieved, perpetuated and put into practice. Nowadays, this technique is no longer commonplace, and is regarded as a complex and unfamiliar process, as compared to the new metal roofing techniques using flat tiles fixed in place by wire, or asbestos sheets screwed to metal structures. (Fig.10)

\subsection{HORIZONTAL FRAMEWORK}

Technique: The technique of creating a flat structural support consists of intertwining thin reeds by placing them next to each other horizontally and attaching them with rope made of organic material to the thicker transverse master reeds that provide support. The space between the reeds varies according to the rigidity desired. This technique is applied to the roof as well as the attic and the gable ends (Sanchís Guarner, 1999:23).

Restoration: The frame of the wall and entortado ${ }^{3}$ need constant care and annual inspections to maintain them in good condition as damage may be caused by small leaks from the roof or footfall on the organic structure. Depending on the extent of the damage, the frame can be strengthened by adding more reeds or simply by reinforcing it with a renchido ${ }^{4}$ that can substitute or be added to the clay mortar coating. In the case of horizontal frameworks, wooden planking placed on top of the plaster will mitigate damage by evenly distributing the weight of tiles etc. (Fig.11)

\section{HISTORICAL, CULTURAL, EDUCATIONAL AND SOCIAL VALUES}

The indigenous, age-old collective spirit of a community must be sought not in churches, castles or palaces, but in its popular architecture. These dwellings, deeply rooted in and

\footnotetext{
${ }^{3}$ Entortado - Reed framework covered with a layer of clay and straw that plugs the gaps and irregularities in the intertwined structure and allows temporary movement.

${ }^{4}$ Renchido - Layer of plaster of variable thickness.
} 
marked by the land, the weather and landscape, are directly dependent on and perfectly adapted to the environment, as a result of a transformation, in which the land provides the prime material and man the transforming capacity. There is a third factor that brings these two elements into contact: necessity, without which the transformation of the geographical features of the landscape into dwellings would not take place.

The popular artist only creates what he knows. He expresses forms as a reflection of needs. He rejects all that is incomprehensible and useless; his art is deep-rooted in this solid and traditional foundation. People build empirically, working directly with the material, without rectification or design. In spite of this, popular collective genius has numerous channels of expression, so that its creations can be considered art and in turn, inspire others.

Some basic questions must be considered to justify the conservation of such buildings, who should undertake it and following what criteria. Whether they are a representation of a now lost way of life, whether they are preserved for their spatial and architectonic qualities, or whether they are preserved as museum pieces; all these issues must be taken into consideration in policy-making decisions. Some believe that awareness of our ties with the past should be a priority; for others, the beauty of the shapes and use of materials wholly justify their preservation and render it essential.

The present paper clearly affirms the urgent need for intervention in order to bring a new approach to the heritage of our urban and natural environments dating from the beginning of the $20^{\text {th }}$ century. These popular architectural elements of undeniable historical and artistic value must be recovered by creating a strategy to reawaken interest in and revitalize these buildings.

Regardless of their present state, would it be logical to exclude the people that are still using and enjoying the barracas their ancestors built? These buildings have obviously been modified or transformed to adapt them to present living standards through minor modifications, and for 
which a rehabilitation plan should be introduced that follows certain rules with minimum intervention. (Fig.12)

Would it be logical to exclude farmers who are still actively working in the fields around their barracas? As part of a strategic plan for the rural surroundings of Valencia, their sustainability should be analyzed and support given to safeguard production and guarantee the sale of their products through their own collective area brand or a protected designation of origin. Could financial incentives be provided for farmers who maintain their barracas to store their farm equipment or simply for pleasure, by allowing them to create rural accommodation or other tourist activities in addition to their usual tasks? Perhaps a series of measures is necessary to ensure the rural lifestyle remains a viable option, and allow owners to repair and even resume the traditional techniques of the barraca as an attraction for visitors, similarly to the competitions held in the early twentieth century.

But, what can be done with buildings that have been abandoned or expropriated? The options are unlimited: any new initiative undertaken by an artistic or cultural organization could breathe new life into the barraca and its surroundings. Land or buildings given over to environmental associations or research centers should provide a meeting point to ensure the sustainable upkeep of these traditional spaces without representing an economic burden.

A rural dwelling is not simply the result of a geographical or human intervention; it is the hallmark of the geographical environment and the human factor. Its appearance not only depends on the environment or its heritage, but on both.

The study of this popular art is a very complex task that requires a great deal of patience. In the wise words of Torres Balbás, 'The accurate, profound knowledge of the land, man and his dwellings is neither easily nor quickly achievable; none of them reveals their secrets before a long and intimate relationship has been established'. (Fig.13)

\section{EUROPEAN ADDED VALUE}


According to the theory of Max Thede, the original Valencian barraca must have resembled a type of Mediterranean cottage as described by Vitruvius: 'it was a hut or cabin crudely built with light materials for temporary use' (Vitruvio, 2000). Sanchis Guarner's interpretation of this description suggests that it provides indirect proof of the pre-Roman origin of the barraca (Sanchís, 1999).

The barraca is a typical building found in alluvial areas with abundant mud, clay earth, reeds and straw. This unique dwelling, typical of agricultural regions of Valencia and Murcia, is considered to have evolved from the thousand-year-old shelters found in Camargue, Languedoc and the Eastern Pyrenees (France) or in the Province of Venice in a more perfected version, depending on the needs of the land and the times (Queralt, 2008).

It should be remembered that throughout the Mediterranean, man's dependence on water and the essential need for artificial irrigation has greatly influenced the way those who live near rivers build their homes. This factor, inextricably linked to their farming activity, has not derived in uniform building styles, since it is widely recognized that in the inhabitants of this area are driven more by their own tastes and creativity than by external impositions.

\section{SPECIFIC RESULTS FROM THE RESEARCH IN THE FIELD OF OUR CULTURAL}

\section{HERITAGE}

I believe that the objectives established to provide clarity and accuracy on European and National Cultural Heritage have been achieved in this study.

- Understanding the process of 'cultural assessment' of architectural heritage through complex philosophical and artistic methods originating in Central European regions at the beginning of the $20^{\text {th }}$ century.

- Detailed explanation of the traditional measurement system used, the building process and techniques that comprise this study and which serve as a documentary record and possible guide to a cultural heritage that has fallen into disuse. 
- Classification of the last remaining dwellings as an "endangered species" in order to encourage a plan for the recovery, maintenance and reuse of the cultural heritage common to delta regions and whose application is worthy of consideration in other European regions. (Fig.14) 


\section{REFERENCES}

- AA.VV., (1986): “La tierra como material de construcción”, II Encuentro de trabajo Navapalos. Soria: Universidad de Valladolid - CSIC.

- Bardou, P., Arzoumanian, V. 1986. Arquitecturas de Adobe. México: Gustavo Gili.

- Cardwell, R. 1994. Blasco Ibáñez: La barraca. Valencia: Grant \& Cutler Ltd.

- Ciscar, A. 1974. “La barraca del bajo Segura”. Cuadernos de Geografía, 14, pp. 47-60. Valencia.

- Corachan, J. B. 1735. Aritmética demostrada teórico-practica para lo matemático y mercantil. Barcelona: Pablo Camping.

- De Hoz, J. et al. 2003. Diccionario de tierra tradicional. San Sebastián: Nerea

- García, V. 1988. Llibre dels privilegis. Valencia: Vicent García.

- García-Esparza, J. A. 2004-2007. Archivo fotográfico. Valencia: Inédito.

- García Mercadal, F. 1930. La casa popular en España. Madrid: Espasa Calpe.

- García Mercadal, F. 1980. Sobre el Mediterráneo: sus litorales, pueblos, culturas:

(imágenes y recuerdos). Madrid: J. Sánchez.

- Gieses, W. 1951. “Los tipos de casa de la Península Ibérica”. Revista de dialectología y tradiciones populares. pp. 563-601. Madrid.

- Gosalvez, V. 1998. La barraca valenciana. Valencia: COATV.

- Houben, H. Guillaud, H. 1994. Earth Construction (vol 1). London : Intermediate Technology Publications.

- Lampérez, V. 1922. Arquitectura civil española de los siglos I al XVIII. Madrid : Saturnino Calleja.

- Maldonado, L., Vela, F. 1997. De Arquitectura y Arqueología, Madrid, Munilla Lería.

- Mateu. F. 1955. “Brevísima historia del Grao de Valencia”. Valencia Atracción. XXX, Febrero. p. 10. Valencia. 
- Medina, J. 2002. “La fábrica, la casa, el palacio: Frank Rank y Alfredo Baeschlin, dos “Heimatschützer” en España”. Actas del Congreso internacional de arquitectura, ciudad e ideología antiurbana. E.T.S.A.

- Montero, J. L. 2005. Nuevo proyecto de reconstrucción de la Torre de Babel. A Coruña: Inédito

- Nourissier G. et al. 2002. Arquitectura tradicional Mediterránea. Barcelona: Grup 4, Ecole d’avignon, Col.legi d’Aparelladors i Arquitectes técnics de Barcelona, Ecole des arts et métiers traditionnels de Tétouan

- Queralt, M. C. 2008. “Les barraques del Delta de l’Ebre. Una arquitectura mil.lenària”, Caramella. Música i cultura popular, 18, pp. 6-9. Reus.

- Ruiz, J. V. 1999. Construint una Barraca Valenciana. Valencia: Ajuntament d’Alboraya. - Sanchis, M. 1999. Les barraques valencianes. Valencia: Institució Alfons el Magnànim. - Tarragó, S., El Pla M. 1980. “Síntesis de trabajo del G.A.T.C.P.A.C en Barcelona”, 2C Construcción de la ciudad 15-16, pp. 68-65. Barcelona.

- Thede, M. 1933. "Die Albufera von Valencia. Eine volkskundliche Darstellung", Volkstum und Kultur der Romanen VI, Hamburg., pp. 225-262.

- Torres Balbás, L. 1933. “La vivienda popular en España”. en F. Carreas (dir.): Folklore y costumbres de España, vol III .pp. 137-502. Barcelona: A. Martín.

- Vitruvio, M. 2000. Los diez libros de arquitectura. Barcelona. Iberia. 


\section{FIGURE CAPTIONS}

Fig. 1 Map of the Municipal Area Valencia, Almassera and Alboraia

Fig. 2 Old painting of two no longer existing barracas.

Fig. 3 Drawing of two barracas by Alfredo Baeschlin, 1934.

Fig. 4 Structural evolution by Paul Oliver.

Fig. 5 Sketch of the reconstruction of adobe walls.

Fig. 6a Framework made of organic materials.

Fig. 6b Sketch of framework reconstruction.

Fig. 7 Barraca in the Albufera Natural Park.

Fig. 8 Barraca measurements.

Fig. 9 Reflection of the color of the land in the barraca.

Fig. 10 The andana, space under the roof made with reed thatch frame.

Fig. 11 Reed thatch frame.

Fig. 12 Adobe wall with numerous coats of lime.

Fig. 13 Wood-fired oven from a no longer existing barraca.

Fig. 14 Landscape of the surrounding environment. 
Fig. 1 Map of the Municipal Area Valencia, Almassera and Alboraia

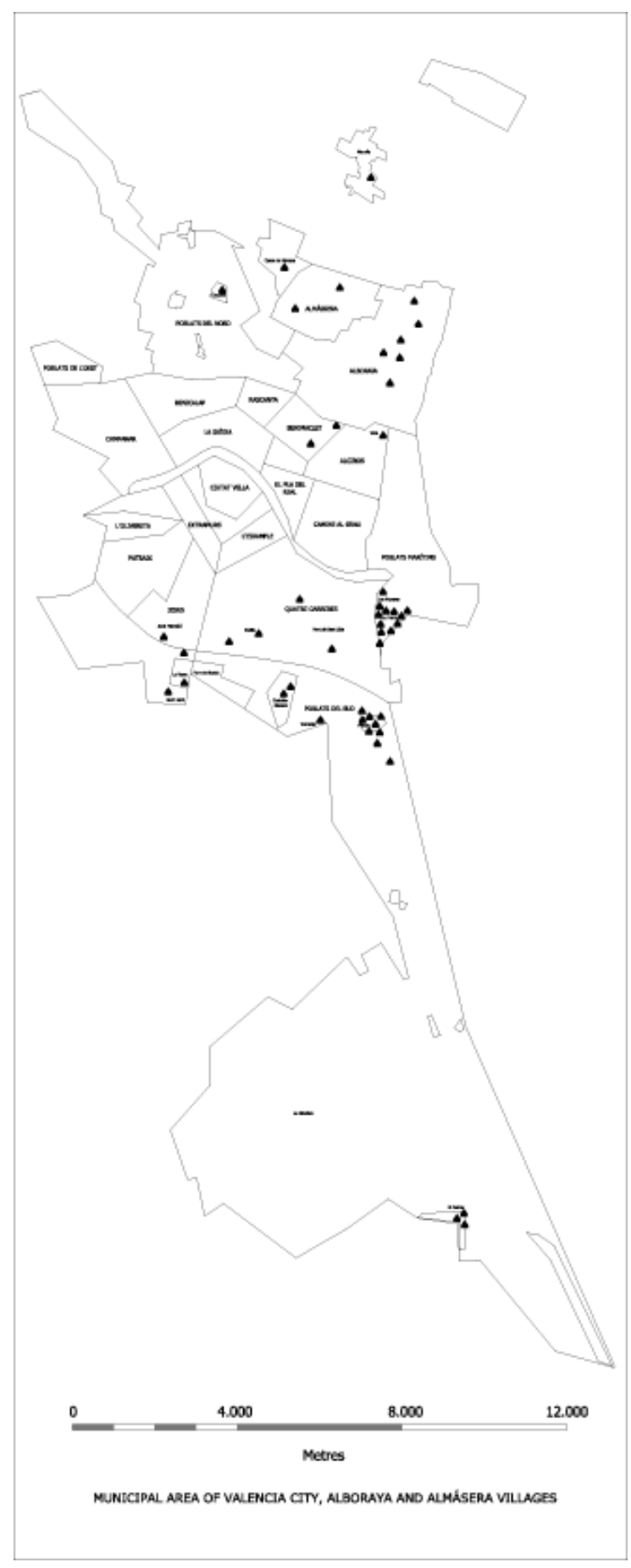

*This map has been reproduced in other publications and is protected by author copyright. Permission to publish has been granted. 
Fig. 2 Old painting of two no longer existing barracas

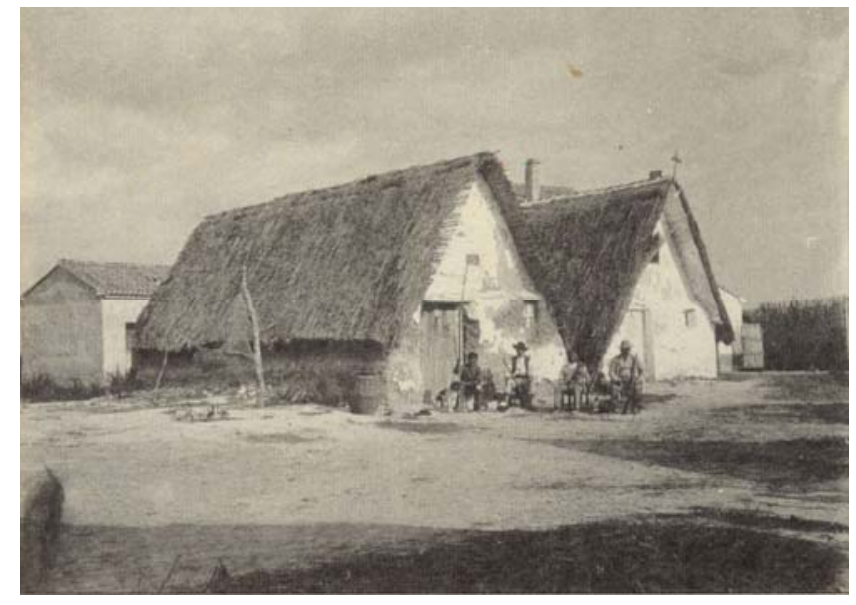


Fig. 3 Drawing of two barracas by Alfredo Baeschlin, 1934

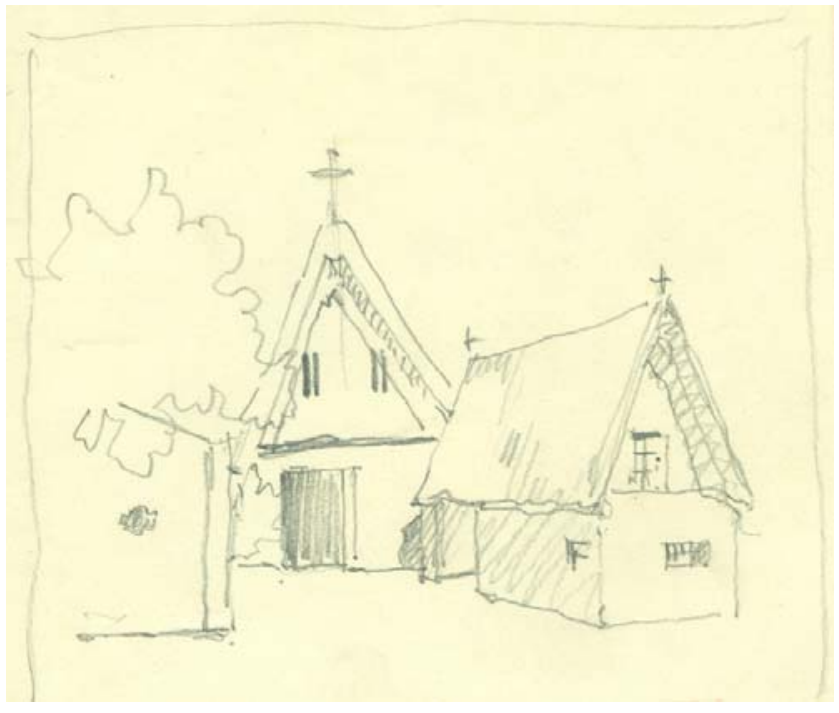


Fig. 4 Structural evolution by Paul Oliver.
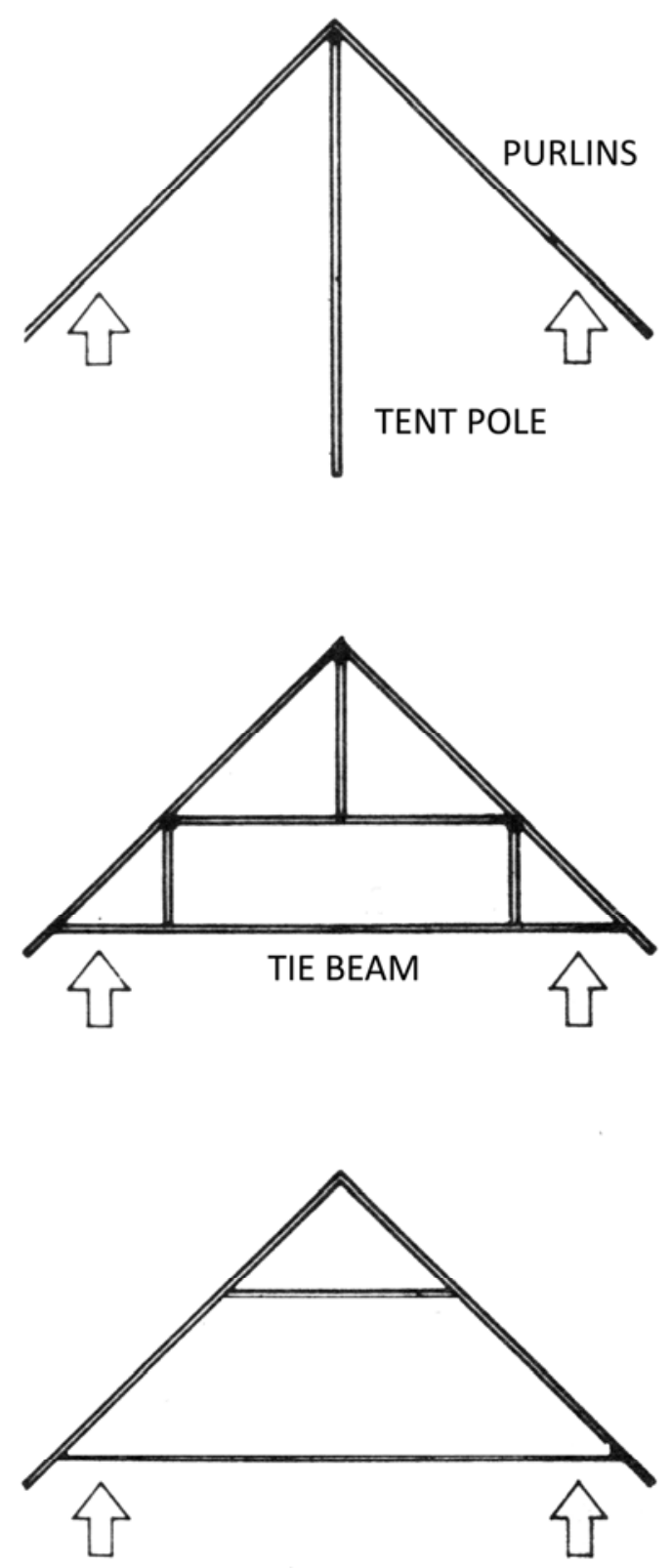

Evolution of the roof structure (simplified)

Fig. 15.1 Tent-type structure: simple, restricted usable space

Fig. 15.2 Intermediate structure: no lower floor pillars, but under-roof space is still restricted

Fig. 15.3 Final shape: the structure moves outwards, freeing up the attic cavity 
Fig. 5 Sketch of the reconstruction of adobe walls.

Deep adobe losses

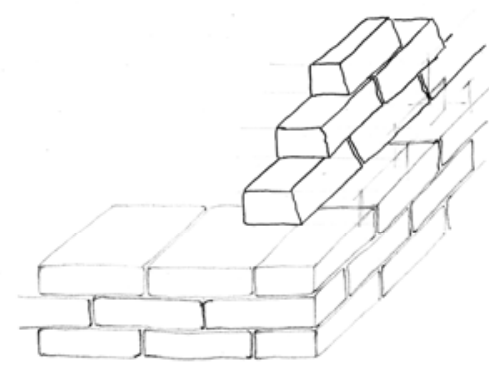

Original material

- Sun dried brick-Adobe

- Mud mortar

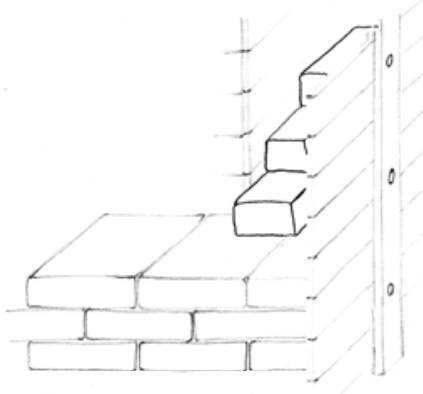

Slightly altered materials

- Mud mortar

- Wooden brackets and anchors

Severely altered materials

- Cement mortar or concrete

- Metallic or fibrous brackets and anchors

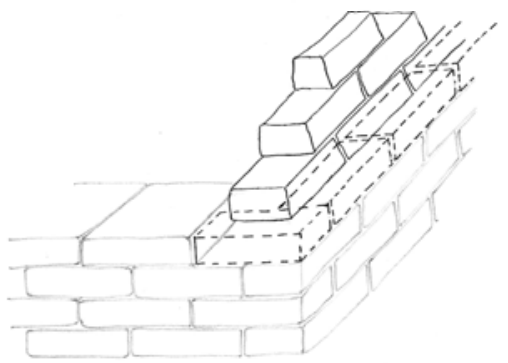

Slightly altered materials

- Soled adobe parts

- Mud mortar

- Brackets and anchors of woor or cane

Severely altered materials

- Precast blocks or prefabricated bricks

- Lime or cement mortar

- Metallic brackets and anchors

\section{Surface adobe losses}
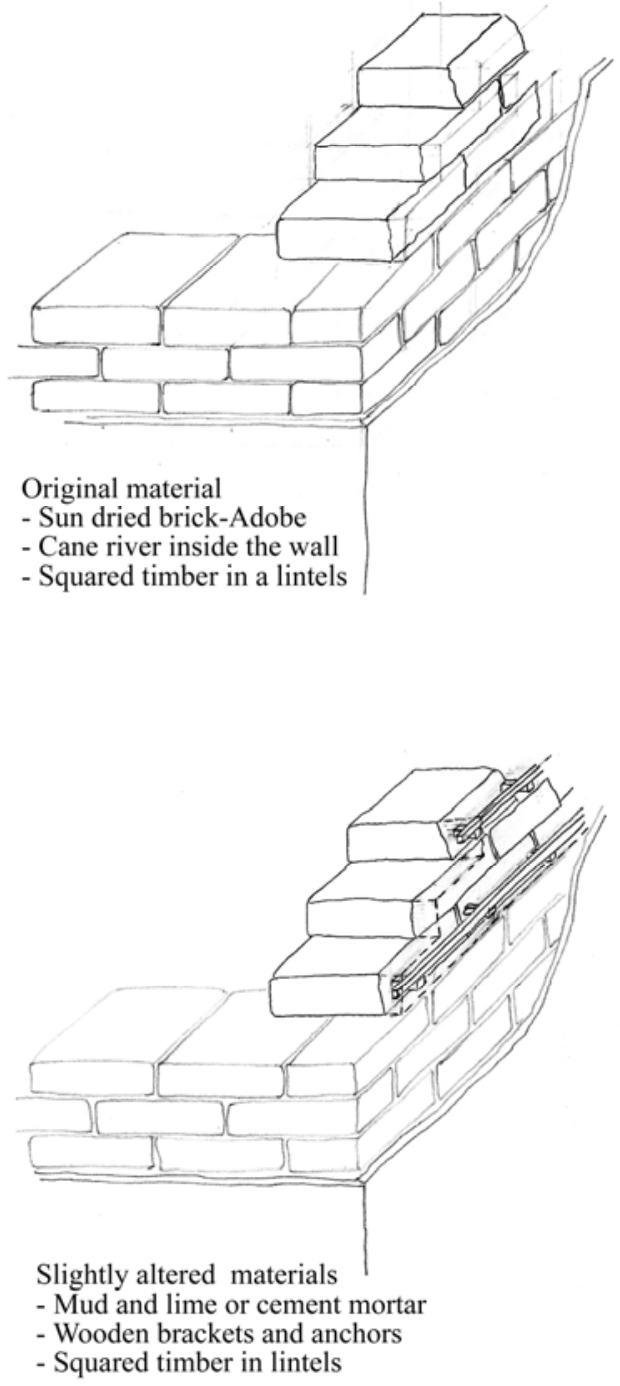

Severely altered materials

- Lime or cement mortar and industrial bricks

- Metallic or fibrous brackets and anchors

- Metallic or concrete elements in a lintels 
Fig. 6a Framework made of organic materials

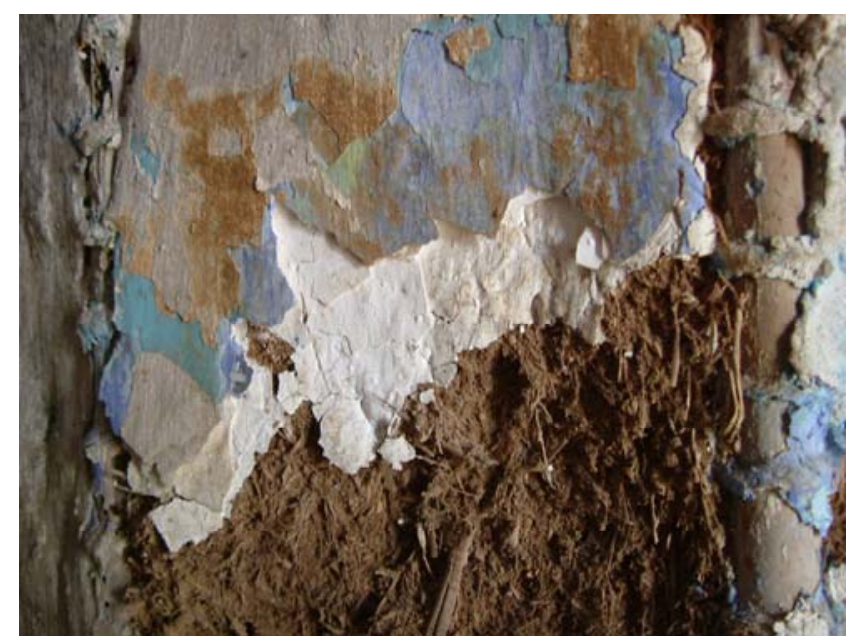

Fig. 6b Sketch of framework reconstruction
Vegetable framework alterations

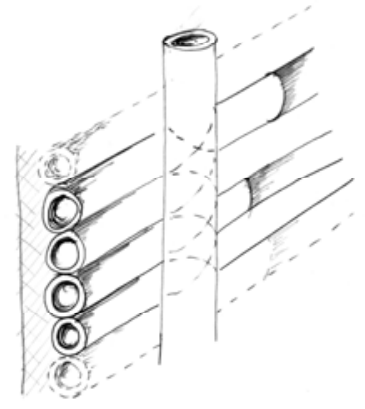

Original material

- River cane and esparto rope

- Mud mortar

- Lime slurry, whitewashed

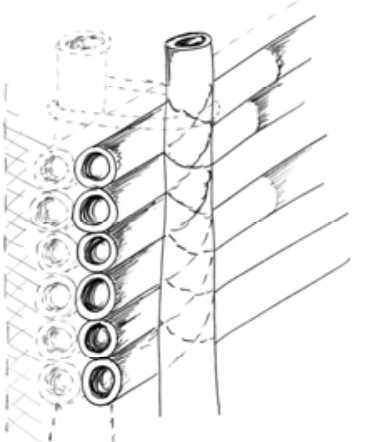

Slightly altered materials

- Cane river and fibers rope

- Mud and lime mortar or gypsum mortar

- Whitewashed or mineral paints

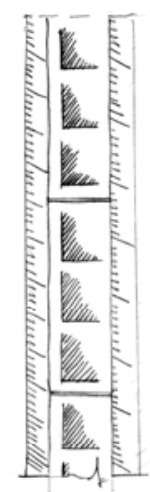

Severely altered materials

- Replacement for ceramic brick

- Lime or cement mortar

- Tiles / plastic paints 
Fig. 7 Barraca in the Albufera Natural Park

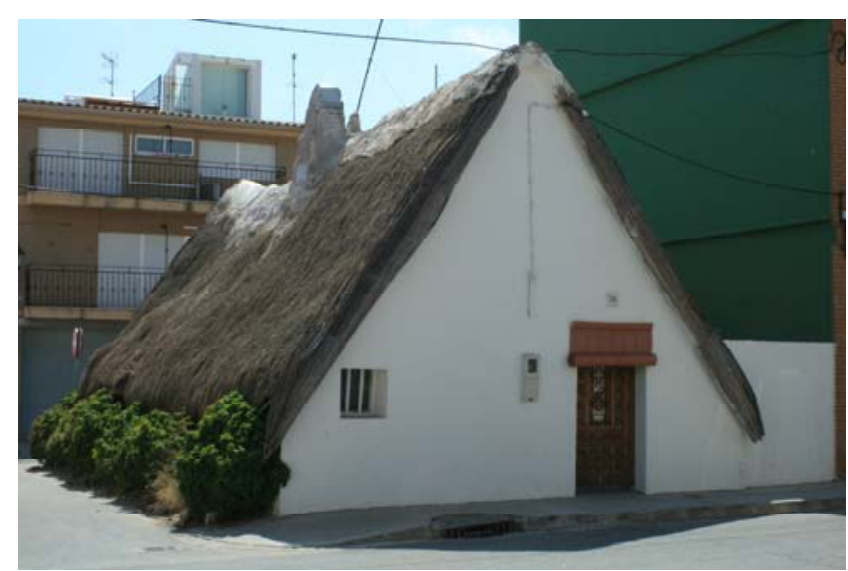


Fig. 8 Barraca measurements

TRADITONAL METRIC SISTEM / DECIMAL METRIC SISTEM: IV = $90 \mathrm{cms}$
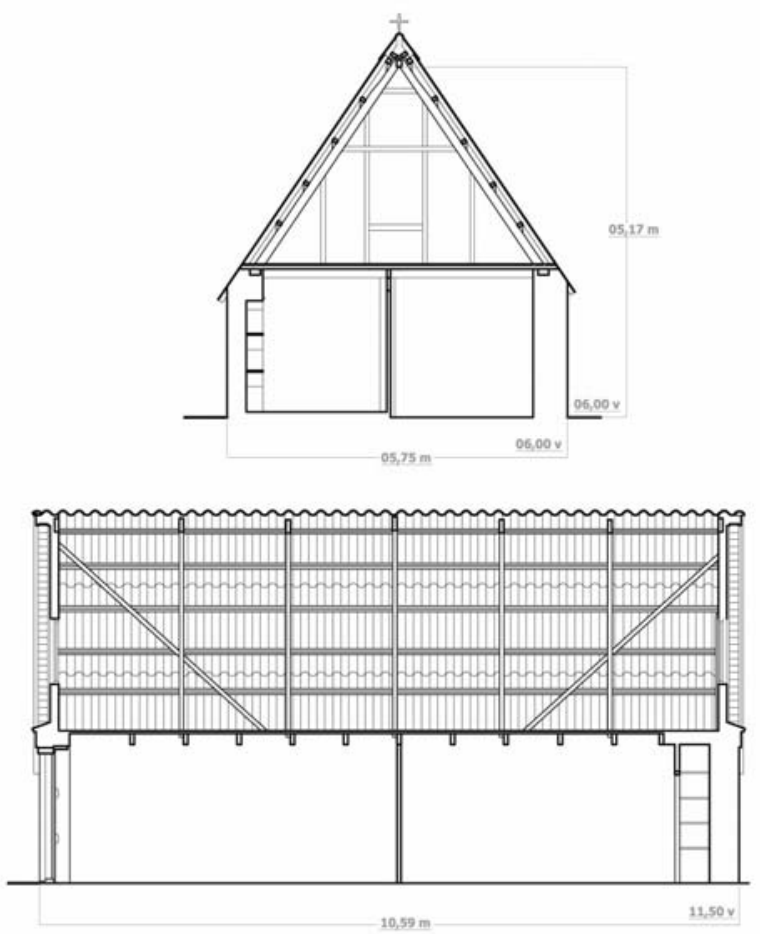
Fig. 9 Reflection of the color of the land in the barraca

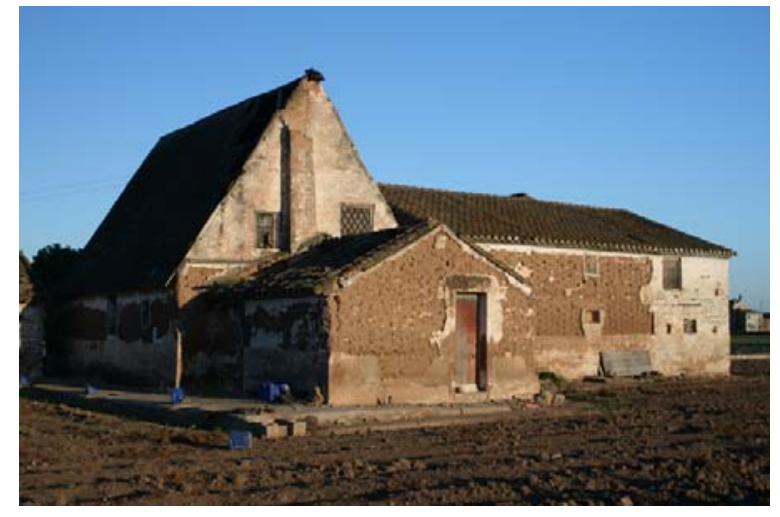


Fig. 10 The andana, space under the roof made with reed thatch frame

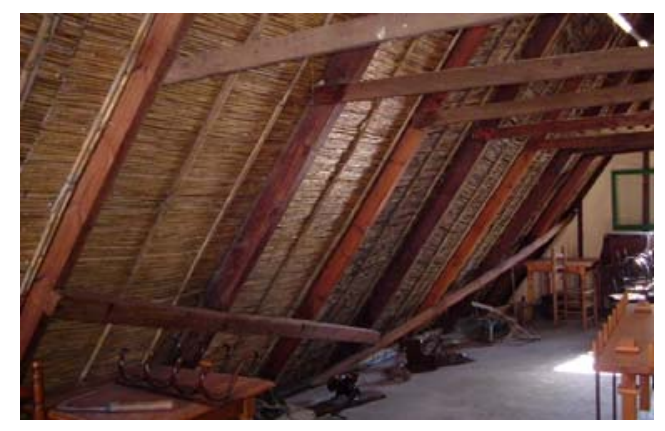


Fig. 11 Reed thatch frame

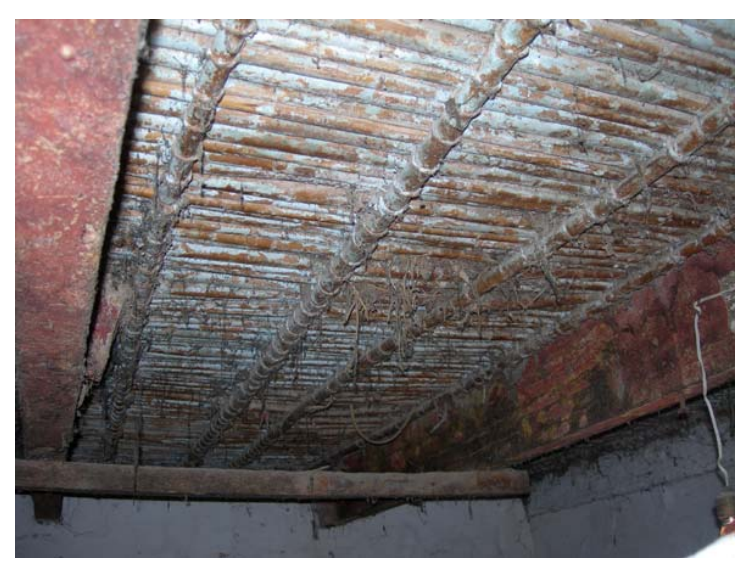


Fig. 12 Adobe wall with numerous coats of lime

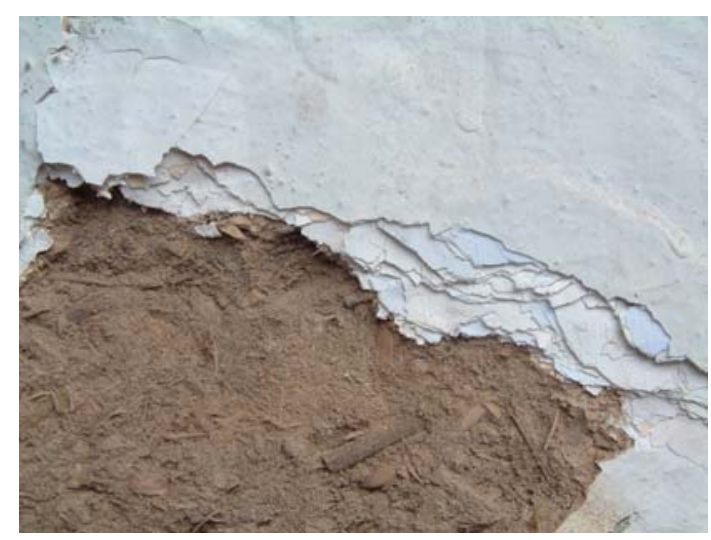


Fig. 13 Wood-fired oven from a no longer existing barraca

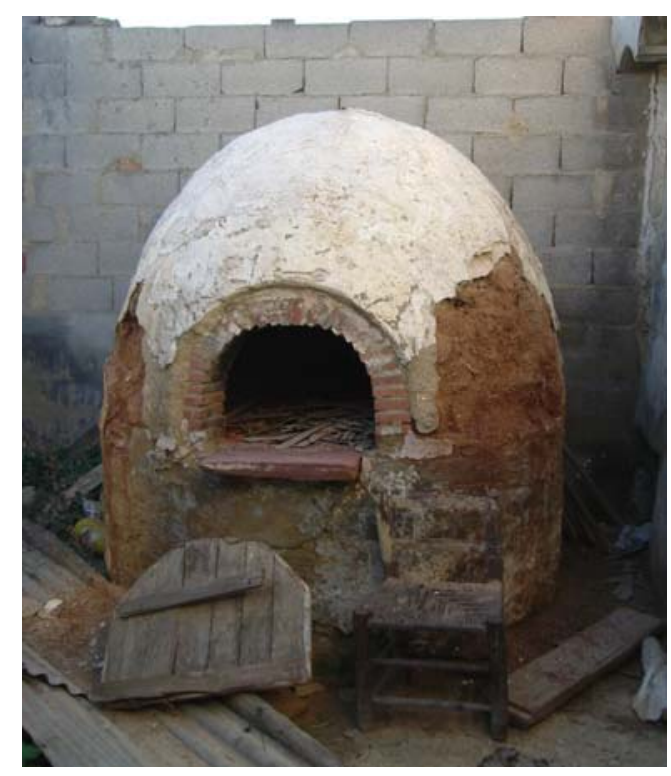


Fig. 14 Landscape of the surrounding environment

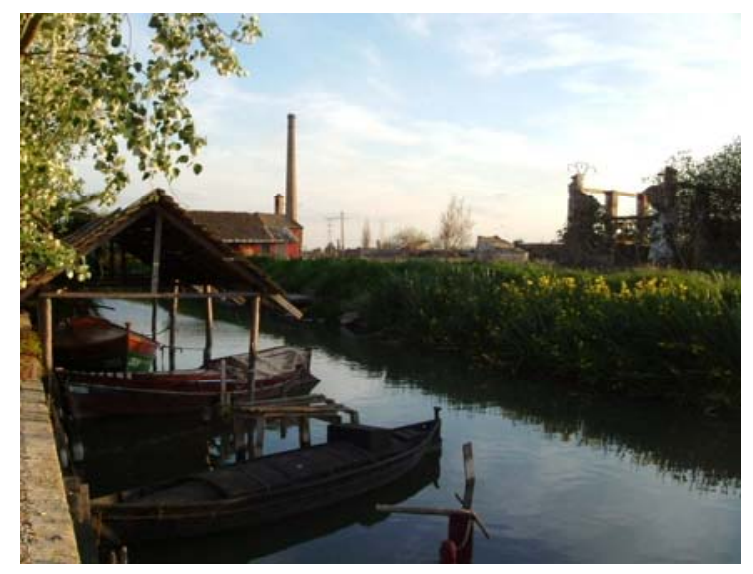

